\title{
Revisiting humanism as guiding principle for education: an excursion into Waldorf Pedagogy
}

\section{Revisitando o humanismo como princípio educativo para a educação: uma excursão na Pedagogia Waldorf}

\author{
Marcelo da Veiga ${ }^{1}$
}

\begin{abstract}
This paper begins by highlight the growing relevance of Rudolf Steiner's thinking within academic discourse. It then turns to a brief discussion of the consequences of physicalism and naturalism in education. In a third step, the concept of notional instrumentalism is presented as a possible way of overcoming the generally unfruitful debates about the comprehension of non-physical aspects of reality. All this serves finally to stress the importance of revisiting humanism as a potential guiding principle for education.
\end{abstract}

Keywords: epistemology; education; humanism; Rudolf Steiner.

\section{RESUMO}

O texto ressalta inicialmente a relevância do pensamento de Rudolf Steiner no discurso acadêmico. Em segundo lugar, trata-se de discutir sucintamente as consequências da visão fisicalista e naturalista para a Pedagogia. Numa terceira etapa é mostrado como uma compreensão dêitica de conceitos possibilita superar infrutíferos debates ideológicos acerca da compreensão de aspectos não físicos da realidade. Tudo isso serve como base para realçar ao menos a importância da renovação da ideia humanista com o objetivo de investigar seu potencial como base da educação.

Palavras-chave: epistemologia; educação; humanismo; Rudolf Steiner.

DOI: $10.1590 / 0104-4060.41417$

1 Alanus University of Arts and Social Sciences. Alfter, Germany. Villestraße 3, 53347. 


\section{Anthroposophy as a method}

Rudolf Steiner did not present his work within the context of the academic life of his time. However, his thinking has had a significant impact over the course of the $20^{\text {th }}$ century, and his books have been read and are still read by many people worldwide. This is nothing unusual in itself, since other important figures in cultural history like John Locke, Francis Bacon and Sigmund Freud shunned, or were shunned by, the academic establishment. Yet, over the last 15 years both Steiner's contribution to education and his philosophical approach in particular have become increasingly a subject of academic research, particularly in the German-speaking world (ZANDER, 2007, 2011; TRAUB, 2011; ULRICH, 2008; HEUSSER, 2013).

This can at least be partly attributed to the fact that Steiner has been and continues to be a relatively unexplored figure. While many better known philosophers have been discussed to death, there is still much to say about Steiner, and it is this that is attracting the attention of a new and broader audience. Scholars who might normally write on other subjects are now, strangely enough, eagerly promoting themselves as experts on Steiner. They are at the same time very keen to declare - notwithstanding their dedicated interest in Steiner - that they are doing so only from an outsider's perspective, that is, without identifying themselves personally with Steiner's point of view. And, as if this were not enough, they would go even further and deny those who endorse or defend Steiner the capacity for impartial judgement. This is a curious claim, since nobody would take a critique of Kant as being more adequate only because the author of such view is a follower of Hegel or Wittgenstein and not a follower of Kant. On the contrary, it is common sense that someone who really immerses into something and identifies with it to a certain extent is more likely to become an expert than one who is a mere bystander or is just keeping himself at distance. Doesn't one need to love Mozart or Beethoven in order to understand their music in depth?

There are of course counter-arguments to this. For example, that the fervour for a philosophical stance doesn't prove its truth. Another example might be that if you want to study drug addiction, you would do well not to become a member of your target group. But there is a significant difference between abandoning oneself to something and embracing and endorsing ideas after having studied them with passion. In other words, so-called critics from 'outside' might contribute a valid perspective but they are by no means more objective than those who get to know a philosophical stance as 'insiders'. On the contrary, 'outsiders' can at least be equally biased, if, for example, they fall into obstinate or emotional 
rejection. A loving gaze without complete submersion in the object of study seems to me to be a much more recommendable route to accurate knowledge.

Besides, to follow an author in his philosophical thoughts means first of all to attempt to meet a question and to endeavour to grapple with a problem that the author has set out. Secondly, it is the encounter with a possible solution or the suggestion of a possible solution that is valuable for the reader's search for comprehension. Philosophical thinking does not aim at imposing a view on its reader. It rather tries to expound possible access to a question and incidentally perhaps, to a solution. The subject in question, say the problem of 'freedom' or 'truth', or even a more mundane subject such as 'the bicycle and its importance today', is likely to be general and not the sole property of the author dealing with it. Even when the mode of getting to grips with it is peculiar or even subjective, the subject addressed is still a public one that can be shared with others. We don't remain isolated within a given train of thought because we start to think on our own about it. In adopting someone else's view, only a partial perspective can be gained for the reader, a real solution comes about only if actual insight into the matter in question arises. Insight sets the reader free from the restrictions of the already defined thoughts of others, and enables that I form my relationship to the core of the theme, and in this sense it becomes my theme.

There are definitely no more reasons for concerns regarding Anthroposophy than for other philosophical perspectives, if, it is understood as a method rather than a doctrine. Whoever delves into Steiner's works does so properly if she aims at experiencing a perspective, that is, a specific perspective to certain questions explored by the author. The validity of the proposed view can be assessed when autonomous thinking sets in and investigates the question independently of the author.

\section{Beyond physicalism}

[...] we must acknowledge that science is an open-ended inquiry, and it is at least conceivable that one day there will be natural sciences that are not physical sciences. (GOLDBERG; PESSIN, 1997, p. 7).

Scientific knowledge is justifiable and reliable knowledge. It is devoted to objectivity and therefore expected to be unbiased. To be unbiased implies avoiding premature judgements in the analysis and investigation of something, and it also implies that presuppositions are questioned. However, there seems 
to be a certain bias when it comes to addressing subjects or phenomena that are non-physical or notional. Notional phenomena are not observable in the normal sense since they do not constitute physical objects. We can address them but not by means of physical sense perception. Moral values, for instance, are principles that exist as notional principles given that they do not coincide with perceivable or measurable entities. The justification and reliability, say of the principle of justice or the idea of freedom, is experienced as an intuitive insight and doesn't rest on empirical facts. On the contrary, it guides human action and claims to become real through action. But even in the case where we come across a just or free action through empirical means, it is but an example of freedom or justice we meet and not the principle as such.

Moreover, in history we learn that thinkers and mythological poets regularly referred to metaphysical beings such as gods, angels etc. They are common in almost all religions and constitute a very old cultural heritage of humankind (HÜBNER, 1985). We are able to think about them and explore them hermeneutically. While on the one hand, it seems perfectly acceptable to address those entities as real objects of cultural history, on the other there is an enormous resistance in dealing with them as ontological realities, or at least in the context of academic discourse. It is taken for granted that there are no such things, in spite of the fact that the relevance of spiritual matters is extraordinary high, not least since they play such a decisive role in many people's everyday lives. For this very reason these notional entities are tolerated only as long as no ontological claim to reality is made about them and they are kept merely as matters of tradition or private belief.

An explanation for this seems to be quite simple, and could be summarised as the following. There is a tacit and almost religious belief that physical reality is ultimately the only reality there is. Although there are more and more scientists practising meditation and methods of contemplative inquiry ${ }^{2}$, the prevalent scientific worldview still tends towards physicalism or naturalism. This is the presupposition that reality is comprised of essentially physical objects and events, as approximately described by the physical sciences, and that thinking and other notional phenomena are the result or effect of things going at this ultimately physical level. Ultimately the human being is thus pictured as essentially a sum of physical events and processes that lasts only as long as these physical events and processes last.

This reductionist ${ }^{3}$ view and its accompanying interpretation of the nature of the human being with its implicit omission of the spiritual is unlikely to inspire

2 See for example: $<$ http://www.mindandlife.org $>$.

3 Of course there are many nuances to how the mind/body relationship is conceived in physicalist accounts, and not all of them are purely reductive. 
education and pedagogy in any real or lasting way. A teacher in a classroom or an educator in a pre-school who is tacitly influenced by the assumption that we are but complex chemical processes will find little to inspire a genuinely human pedagogical practice. However, rather than drawing motivation from religious traditions or philosophical humanistic ideas of the past, the real challenge, I would say, is to find ways to go beyond physicalism by developing competence for justifiable and reliable knowledge that can engage with and comprehend the non-physical aspects of the human being.

\section{Steiner pedagogy and its idea of humanism}

Steiner pedagogy or Waldorf education draws upon the attempt to ground teaching and learning on a holistic view of the human being. This holistic approach aims at addressing the non-physical aspects of the human, and sees these as being equally relevant for pedagogical action as is the physical. Its remarkable results, confirmed by several theoretical and empirical studies (DA VEIGA; RANDOLL, 2013; DA VEIGA, 2011, 2014; BARZ; RANDOLL, 2007; ULRICH, 2007, SCHIEREN, 2012 etc.), can certainly be studied without considering their theoretical background. Yet they are ultimately not divorceable from methods of thinking and observing that encompass non-physical aspects of reality along with the physical.

But how is this possible? Common sense thinking deals normally with phenomena given to sensorial perception, that is to say, with the physical reality of things. As a consequence, thinking is construed nominalistically as depicting or picturing objective, perceived reality. And of course there are many thoughts and representations that are strictly related to perceived things. I can form mental pictures of my bicycle or a tree in the garden that are imbued with details perceived in a specific moment. These mental pictures reproduce an object given to the observer from a particular perspective. Moreover, we can elaborate on those mental pictures later, for instance by analysing and drawing out implicit yet initially undetected parts of the perceptual experience, or by combining different picture with one another. Thinking is, however, more than the imitation of perceived objects and situations occurring outside us. In the field of arts, a type of thinking that invents, designs and projects regularly replaces depictive thinking. In poetry and literature thinking resorts as well to real observation, but only to go beyond it when it engineers its fictional plots or invents its yet unseen worlds and scenarios. Everything that accounts for the story has its origin in a 
generative capacity called fantasy. In mythology and religious texts one often finds an even more detached way of thinking insofar as aspects of depicted reality are cast into metaphors, similes and analogies in order to allude to more subtle layers of meaning. The narrative that seems to address events and facts as if they were natural events in truth refers to layers of meaning too tenuous to be captured in more coarse forms of depiction. The meaning addressed by these linguistic devices cannot be found in the natural environment.

If we delve into the theory underpinning Waldorf education we may find an approach even more radical and challenging. The practice of Waldorf education is built upon an anthropological and ontological stance that encompass facts and processes of a non-physical nature. This framework of understanding about the human constitution and other aspects of reality is commonly called Anthroposophy. Anthroposophy can be read as an attempt to expand observation and thinking beyond physical reality in order to attain reliable and justifiable knowledge about non-physical reality. This has the aim of bringing about an integration of physical and non-physical dimensions. It tries to do this by way of a thinking that uses concepts as 'organ of observation' through which new layers of human reality can be disclosed. This is a significantly different posture towards thoughts and the engagement with them than the one outlined above. Thoughts are not measured as to their capacity to depict or represent reality but rather as to their aptness to apprehend reality in a more complex and differentiated manner. This is a quite distinct approach from empiricism as commonly understood, which believes in a reality exclusively given to sensorial observation and sees in thinking the capacity to capture, through concepts and theories, objective physical facts that are entirely independent of any attempt to comprehend them.

In Steiner's approach the reader is confronted first of all with thought contents that are not derived from physical reality but which at the same time seem to suggest a sort of notional instrumentalism. This instrumentalism assumes that phenomena or data show their properties only in the light of notional lenses brought about by thinking. However, those lenses do not anticipate reality, given that real things require as well perceptions in order to impart to the knower what is singular and particular. To be sure, reality cannot simply be logically inferred from theoretical assumptions, neither can it be simply collected from so-called empirical data, for we identify only those features of a thing that we have already to some extent cognised. What can legitimately be called a real object is a set of properties that present themselves in the dual field of sensorial and notional experience. Empirical data free from thinking is mere impression without meaning. What is in fact given to sensorial perception is a continuous flux of appearances, stable in some properties and changing in others. A perceived 
tree in the garden proves only to thinking to be an oak tree that is taller than others in its surrounding, having a certain foliage, etc. As a perceived object it is an ever-changing appearance that is colourless in the twilight, brown and green in daylight and under other circumstances perhaps greyish. Identifiable objects are thoughts realized in a specific fashion by concrete experiences, and sensorial impressions furnish only an aspect of this.

If it is possible to construe properties of things as thoughts or notions, than thinking seems to be part and parcel of the real world. To confirm if something is the case, perception is required, but so too is the experience of relation introduced by thinking. A procedure that seeks access to reality based on the dual experience of perceiving and thinking can be named scientific when it obtains its judgement in an experiential manner and avoids presuppositions. Accounts that are based merely on presuppositions or institutional or some other authority and infer results on this basis are, in contrast, dogmatic.

A scientific stance that relies on physical organs of perception as its primary means of validation is called, by Steiner, natural science. In contrast, a cognitive method that builds its organs throughout the process of cognition is called spiritual science. Natural science and spiritual science are both experiential ways of acquiring knowledge and therefore different from knowledge that draws dogmatically on truths conveyed by authority. The difference between them lies in the attitude regarding the process of thinking and its significance both for the knowledge seeking subject and the object. They have in common the aim of achieving reliable and justifiable knowledge, yet they differ as to how facts enter the field of perception, since in spiritual science facts presuppose an active participation on the part of the subject in their coming into being.

[...] spiritual scientific facts enter into our perception only through activity on the part of the soul. Thus those presenting spiritual science presume that the reader is accompanying them on the search for these facts. (STEINER, 1997, p. 18).

What Steiner calls spiritual science is hence a complementary approach to natural science and not contradictory to it. Its justification however demands thorough epistemological inquiry in order to identify within cognition the point of departure for recognising spiritual realities. Steiner was keen to show that there is in fact a modern way of relating to spiritual realities that complies with the scientific method. He proposed expanded forms of observation that can be trained by modifying the relationship to thinking. 


\section{Body, soul and spirit}

Steiner's approach has implications for the value and role of theory in research ${ }^{4}$. Theories are composed of thoughts and are generally meant to explain and understand reality. Besides the theories of the natural sciences, which are basically mathematical or schematic models relating to occurrences and facts that may be too small, too big or too distant to be directly observable, we find as well another level of theory that purports to shed light upon existence in general. These universal philosophical ideas have come increasingly to be seen as misleading 'grand narratives' imposed on reality by their authors. However, following the train of thought discussed in the previous section, the role of theory can be seen differently. A theory or a combination of thoughts has a different function when used to create awareness and direct attention than when use to define or specify a fact. In this vein, the idea of a table, for instance, when used to direct attention, does not prescribe beforehand how the object should appear. It simply furnishes a lens through which a given sequence or field of perceptions can be structured. If nothing is met in the field of observation that allows for interpretation according to the given theoretical lens, it remains a mere possibility of thinking.

The same applies for overarching ideas like that of 'materialism' or 'mechanism' or 'causality'. Instead of arguing about the theoretical truth of such concepts in general terms one can use them to analyse natural and cultural phenomena. Observation will then show where and how these concepts prove capable of getting to grips with given phenomena. Where and to what extent an idea is applicable cannot be decided only through thinking. It needs to be confronted with observable phenomena and experimented as to its explanatory power. This means that the idea per se is not right or wrong, but rather, that the way it is used to connect data in a given instance is effective or not. It is also possible to read Steiner's suggestions regarding spiritual reality in a similar way. Instead of construing his claims as all-encompassing explanations or statement

4 "Readers must first absorb a fairly large number of super-sensible experiences recounted by others without experiencing them personally. This cannot be otherwise and will also be true of this book. The author will describe what he believes he knows about the nature of human being and what happens to them at birth, at death, and in the body-free state in the spiritual world. He will also describe the evolution of the earth and of humanity. It could seem that a certain amount of alleged knowledge is being presented like dogma, as if belief based on authority were called for. However, this is not the case. In fact, what can be known about the world's supersensible content is present in the author as a living soul content, and immersing yourself in this content kindles impulses in your own soul which then lead to the corresponding super sensible facts". (STEINER, 1997, p. 291). 
of truth or fact, one can adopt them as a means of observation, although not without having analysed and scrutinized them accurately beforehand. Seeing the role of spiritual ideas in this way, i.e., as a means to facilitate observation, can contribute to less ideologically based claims with respect to the existence of spiritual realities.

To be more specific, I will pick an example from Steiner's book Theosophy. This fundamental text guides its reader to an expanded view of the human being that in turn grounds the pedagogical approach of Waldorf pedagogy. The central theme here is the distinction between the three layers of the human constitution: body, soul and spirit. These concepts need to be taken with caution in order to avoid seeing them as a mere rehash of traditional metaphysical or religious ideas.

The term 'physical body' seems to refer simply to the body as physical substance and physical process. However, if one follows the description of this notion as it is presented in Theosophy, a different perspective is opened up. Here the idea of the physical body comprises the integration of mineral, organic and sensitive aspects, that is to say, an integration of three distinct qualities. This comprehensive idea of the physical body invites us to look at it differently, and to include in it implicit but usually undetected qualities. Thus the so-called physical is more than simply a compound of material substance, since it appears as endowed with life and sensation.

Like the minerals, we build up our bodies out of natural substances; like the plants, we grow and reproduce; like the animals, we perceive the objects around us and develop inner experiences based on the impressions they make on us. Therefore, we may attribute a mineral, a plant and an animal existence to the human being. (STEINER, 1994, p. 26).

Something similar applies to the concept of soul. Soul is on the one hand the field of 'interiority' and therefore not accessible to the senses. It constitutes a different realm of phenomena that requires, in turn, a specific form of perception. As the domain of interiority, it encompasses on the other hand three qualities, namely: sensation, feelings and volition. The suggestion here is to think the notion of soul in this threefold fashion, and by means of this to observe human life, given that reality is neither given only by thinking or by mere perception. An object is realized only when the content of perception is complemented by its corresponding concept. In this sense, Steiner seeks no theoretical proof of the soul or its immortality. What he tries is to direct instead the observer's gaze towards phenomena that reveal themselves as constituting the domain of 
the soul for the act of cognition. The idea of integration and interaction of the three functions mentioned before (sensation, feelings, volition), accounts for the essential trait of the inner or subjective realm of interiority. In this light a confluence of forces and processes that together make up the specific character of the soul may be observed.

Feeling follows closely on sensation, with one sensation arousing pleasure in us and another displeasure. These are the stirrings of our inner soul life. We each create an inner world of feelings in addition to the world that works in on us from outside. Then there is a third factor, our will, through which we work back upon the outside world, leaving the imprint of our own inner being on it. In will activity, the soul flows outward, in a sense. (STEINER, 1994, p. 29).

A third layer of the human constitution reference is made to what is called spirit. We are dealing here with an element of a specific order and essentially different from the parts already mentioned. Spirit means both the nomological (i.e., lawful) essence grounded in itself and the living capacity to commit to it by inner attentive activity. The latter is thinking understood as the experience of autonomous thought production. Steiner's concept of thinking is peculiar insofar as it stresses its emergence within the field of human interiority, i.e. the human soul, and on the other hand, it is the activity that leads beyond subjectivity. In thinking, a person grasps a thought-content but she does so in accordance to the properties that lie in the content itself. When one thinks one apprehends by inner activity a lawful content that belongs to the world, one does not construct something in a subjective way. The possibility of rational discourse and mutual correction of incorrect thought-attempts resides in the fact that the thought content is not derived from the subject as such.

The content experienced in thinking lies by its very nature beyond subjectivity because thinking is the capacity to identify with what is other than self. To be sure, when we think we engage with thought contents like 'cloud', 'tree' or 'street', or more abstract thoughts like 'inflation' or 'evolution' by mingling ourselves with these contents. Thinking is aimed at gaining insight into things or states of affair. It commits and submits to nomological structures grounded in themselves. For that very reason thinking is something other than soul life and constitutes a field of reality with its own properties. 
Out of natural necessity, it [the human soul] is governed by the laws of the body, but because it freely recognizes their necessity it also allows itself to be governed by the laws that lead to correct thinking. Nature subjects us to the laws of metabolism, but as human beings we subject ourselves to the laws of thought. Through this process, we make ourselves members of a higher order than the one we belong to through the body. It is the spiritual order. Soul is different from spirit, as different as it is from the body. This is the spiritual order. (STEINER, 1994, p. 30).

\section{Renewed humanism}

The view of the human being suggested above leads to both a complex and integrative understanding of the human being. However it is not just a new picture to be adopted in place of an old one. The value of this approach lies in expanding and training observation towards the implicit yet hidden inner, spiritual aspects of the human being. This would allow us to see the human being in a different light and to establish new goals for pedagogy. Education is today guided by a short-sighted materialistic conception of the universe in general and the human being in particular, and this tends to foster a preoccupation with material welfare, career progression and social competition. The consequences are well known and are becoming ever more evident. Since there is no other purpose in life, economic success becomes the centre of societal and individual striving. In order to ensure access to increasingly scarce natural resources the militarisation of politics becomes inevitable, though this may not always be visible. There is fortunately no full-scale world-war currently taking place, but there is a constant scaling up of militarisation internationally, and the number of local wars is growing significantly. Control over territories and countries that have natural resources, such as gas and oil, is clearly a strong motivating factor for this. Through an implicit ideological focus on the material, material welfare and economic power became ends in themselves rather than means to enable cultural and spiritual development.

This also has significant implications for education. To go to school and to university is imperative because it is the springboard to a well-paid profession and high social standing. The consequences of poor education are poverty, low paid jobs and low levels of social standing. The educational system thus becomes utterly streamlined to comply with the ethos of 'be better than others in order to get more for yourself'. This applies as much to individuals as to whole nations. Global standardisation and constant measurement of learning outcomes for the 
purpose of quality assurance are the inconspicuous instruments that bolster the somehow perverse modern education industry. It is therefore high time to question the unquestioned assumptions about the nature of the human being that quietly underpin this whole trend.

What is it that we really want to achieve with education? I would like to propose that to pursue this question means giving some serious attention to the expanded view of the human being hinted at above. Any serious attempts to understand the spiritual and inner dimensions of the human being force us to rethink education as to its aims and its methods. It would be wrong, however, to do that by pitting material welfare against spiritual development. The problem lies not so much in the fact that there is a striving for better general conditions of sustenance and comfort, but rather, that when this is taken as the only (if often tacit and implicit) goal, then this has serious social and existential implications. The current challenge is to integrate all dimensions of the human being and to develop further the idea of humanism as the guiding principle of education. To do this it is necessary to rethink how we look upon the human being and to reshape and expand methods of scientific inquiry to correspond with this. What has proven adequate to understand the behaviour of animals does not necessarily serve the understanding of the human being. A much more attractive perspective is at least thinkable, namely, to bring about a conscious spiritual life in a process of all-encompassing cultural development, and to pay gratitude to nature for enabling this.

\section{REFERENCES}

BARZ, Heiner; RANDOLL, Dirk (Hrsg.). Bildung und Lebensgestaltung ehemaliger Schüler von Rudolf Steiner Schulen in der Schweiz. Eine Absolventenbefragung. Frankfurt am Main: Peter Lang Verlag, 2007.

BARZ, Heiner; RANDOLL, Dirk (Hrsg.). Absolventen von Waldorfschulen. Wiesbaden: VS Verlag für Sozialwissenschaften, 2007.

DA VEIGA, Marcelo. Die Bedeutung des philosophischen Denkens für die Waldorfpädagogik. In: WILLMANN, Carlo (Hg). Waldorfpädagogik studieren. Wien: Lit Verlag, 2011. p. 43-58.

DA VEIGA, Marcelo. O significado do pensamento filosófico para a Pedagogia Waldorf. In: DA VEIGA, Marcelo; STOLTZ, Tania. O pensamento de Rudolf Steiner no debate cientifico. Campinas, São Paulo: Alínea, 2014. p. 09-32. 
DA VEIGA, Marcelo; RANDOLL, Dirk (Hrsg.). Waldorfpädagogik in Praxis und Ausbildung. Zwischen Tradition und notwendigen Reformen. Wiesbaden, Springer VS., 2013.

GOLDBERG, Sanford; PESSIN, Andrew. Grey Matters. An Introduction to the Philosophy of Mind. London: Routledge, 1997.

HARSLEM, Michael; RANDOLL, Dirk (Hrsg.). Selbstverantworliches Lernen an Freien Waldorfschulen. Ergebnisse eines Praxisforschungsprojekts, Beispiele aus der Unterrichtspraxis. Frankfurt am Main: Lang, 2013.

HEUSSER, Peter. Rudolf Steiner und seine Bedeutung für die Wissenschaft heute. Stuttgart: Schattauer Verlag, 2013.

HÜBNER, Kurt. Die Wahrheit des Mythos. München: C.H. Beck, 1985.

SCHIEREN, Jost. The concept of learning in Waldorf Education. RoSE - Research on Steiner Education, v. 3, n. 1, p. 63-74, July 2012. Available at: <http://www.rosejourn. com/index.php/rose/article/view/99/124>. Access: 23 Apr. 2015.

STEINER, Rudolf. Theosophy. New York: Anthroposophic Press, 1994.

STEINER, Rudolf. An Outline of Esoteric Science. Great Barrington: Anthroposophic Press, 1997.

TRAUB, Hartmut. Philosophie und Anthroposophie. Stuttgart: Verlag Kohlhammer, 2011.

ULRICH, Heiner. Rudolf Steiner. London: Bloomsbury, 2008.

ULRICH, Heiner. Autorität und Schule: Die empirische Rekonstruktion der Klassenlehrer-Schüler-Beziehung an Waldorfschulen. Wiebaden: Verkag für Sozialwissenschaften, 2007.

ULRICH, Heiner. Rudolf Steiner. Leben und Lehre. München: C.H. Beck, 2010.

ZANDER, Helmut. Anthroposophie in Deutschland. Theosophische Weltanschauung und gesellschaftliche Praxis 1884-1945. Göttingen: Vandenhoeck \& Ruprecht, 2007.

ZANDER, Helmut. Rudolf Steiner. München: Piper Verlag, 2011.

Texto recebido em 18 de maio de 2015. Texto aprovado em 09 de junho de 2015. 
